\title{
FDI in Services and Manufacturing Efficiencies in Host Countries: Evidence from China
}

\author{
Libin Luo \\ Beijing international Studies University.
}

Received 2013

\begin{abstract}
The paper studies the correlations between FDI in services and manufacturing efficiencies in host countries. First a theoretical analysis is presented on the direct and indirect channels through which FDI in services enhances manufacturing efficiencies in host countries. Then the forward linkages and backward linkages between FDI in services and manufacturing sector in host countries are tested empirically using China's industrial panel data. We find that FDI in services has positive forward and backward linkage effects on China's manufacturing sector, with forward linkages stronger than backward linkages, and the wholesale, retail, trade and restaurant sector has the strongest linkage effects.
\end{abstract}

Keywords: FDI in Services; Manufacturing Efficiencies in Host Countries; Inter-industry Technical Spillover

\section{Introduction and Literature Review}

This paper focuses on the correlations between FDI in services and efficiencies of manufacturing sectors in China. The issue is introduced mainly based on the following three phenomena:

First, FDI in service sectors has been growing rapidly during the past few decades. Since 1990s, FDI in service sectors began to cover an increasing proportion of the total FDI, replacing manufacturing and became the most important sectors utilizing FDI. From 1990 to 2007, the share of global FDI stock in services was up from $48.61 \%$ to $63.84 \%$. China witnessed the same trend in recent years. From 1997 to 2008, real FDI utilization in service sectors expanded by $214 \%$; Its proportion in total FDI increased from $26.65 \%$ to $41.07 \%$.

Second, China's manufacturing sector needs to improve its output efficiencies to stay competitive. Great changes occurred to China's manufacturing sectors development environment. First of all, labor costs keep climbing up. From 2003 to 2008, average annual wages of Chinese manufacturing workers almost doubled, making it one of the fastest growing in the world. With the growth in Chinese economy and Chinese national income, labor costs will continue to increase. Second, natural resource constraint is intensified. Energy consumption has been higher than the production capacity. From 2001 to 2008, the gap between production and

${ }^{*}$ This work is supported by a grant from visiting scholar program of Beijing Municipal Commission of Education (No. 11530500015). consumption increased from 57.54 million to 250 million tons of standard coal. In 2006, GDP per kilogram of oil in China is 3.2 dollars, below the world average of \$5.2. Third, the appreciation of RMB will dampen the competiveness of Chinese goods in international market. China's manufacturing industry can no longer rely solely on cheap labor and intensive energy input, productivity must be improved.

Third, service sector is an important source of manufacturing efficiency enhancement. Some producer service inputs, such as research and development, management consulting, mergers and acquisitions, legal services, are just like fixed assets in that their cost and revenues need to be shared for a long time, and they can improve productive technology and managerial skills of manufacturing enterprises; other producer services like product designing and marketing and other producer services and create product differentiation, giving enterprises their competitive advantages. In addition, producer services also help to achieve internal and external economies of scale. In recent years, more and more manufacturing companies contract producer services out, resulting in rapid growth of service outsourcing. Outsourcing brings cost savings and higher qualities. Through outsourcing, manufacturing companies can enhance their core competitiveness, respond to demand uncertainty. Service outsourcing brings better division of labor, striking up the importance of service sector for manufacturing efficiencies.

The importance of producer services and development 
of service outsourcing have resulted in manufacturing sectors greater dependence on service input. Dependence rate of manufacturing sectors on service input in 9 OECD countries has been rising from $16 \%$ in 1970 s to $27 \%$ in early 21 century (S. Li, C. Gao, 2008). While the calculation based on input-output table of China, China's manufacturing industry's dependence on the service industry in decline, but in the long run, as China's economic growth, China's dependence on manufacturing to the service sector will gradually increase.

Most parts of FDI in services provide producer services. For example, in 2007, 86.14\% of world total stock of FDI in services was in areas like finance, trade, business services, transport, storage and communications sector. From 2004 to 2008, 75.8\% of the service FDI utilized by China are in real estate, renting and business services, financial services and the postal industry, transportation, storage. On the one hand, FDI in producer service sectors can directly affect manufacturing efficiencies in the host country; on the other hand, FDI can promote host country's service industry, thus indirectly affecting the manufacturing efficiencies in the host country.

Theoretical studies on the correlations between services sector liberalization and efficiencies of manufacturing industry first appeared in 1980s. Markusen (1989) introduces producer services into the DS production function as intermediate inputs, finding that producer services liberalization can lead to large gains. Markusen et.al. (1990) established a model of producer services, further analyzing the economic benefits of services liberalization to the host country. Francois (1990) finds producer services t obtained by foreign trade or multinational corporations promote specialization in developing countries, playing important roles in achieving domestic economies of scale.

Compared with the theoretical research, very little empirical research in related fields can be found in the literature. The earliest empirical literature is Jensen et.al. (2004), which studies the case of Russia's accession to the World Trade Organization, finding that elimination of barriers to FDI in business services enhances factor productivity in sectors that use business service as inputs. With Czech enterprise data from 1998 to 2003, Arnold et al. (2006) finds that the overall liberalization of services, the presence of foreign service providers, and privatization of services all have a significant positive correlationwith the efficiency of the domestic downstream industries, and liberalization of foreign investment in the service industry is the most substantial contributor among the three. Fernandes, Ana M. and Paunov, Caroline (2008) employ Chile enterprise data between 19922004 and finds substantial positive correlations between FDI in services and labor productivities of downstream manufacturing sectors. Jiang Xiaojuan (2008) finds the presence of foreign designing enterprises promotes manufacturing enterprises competitiveness.

Considering the fast growth of FDI in services and importance of manufacturing sector in China, we need further research on the mechanisms and relationship between FDI in service sector and manufacturing efficiencies in host countries, to help fully understand the role and significance of services FDI, and to help explore effective channels to expedite the transformation and upgrading of China's manufacturing industry.

The rest of this paper is organized as follows: Part two analyzes the direct and indirect effects of FDI in services on manufacturing efficiencies in host countries. Part three tests the correlations between FDI in services and manufacturing efficiencies in China with China's industry panel data, with focus on the forward and backward linkage effects. Part four is conclusions.

\section{Influence of FDI in Services on Manufacturing Efficiencies}

FDI in services influence manufacturing efficiencies in host countries through two channels. In the direct channel, the output of foreign service enterprises is direct input into manufacturing sectors in host countries; while in the indirect channel, the presence of FDI in service local service sector, which in turn benefit manufacturing efficiencies.

\subsection{Direct Channels}

1. Forward-linkage technology spillover. Since most FDI in services exist in the producer service sectors, they provide producer services to related manufacturing industries. Compared with local service enterprises, TNCs with better technologies and human resources (Fernandez, 2001; Griffith et.al., 2004; Lombard, 1990; Karparty and Poldahl, 2006) may provide better services, which can better help improve efficiencies of manufacturing enterprises in host countries. Amiti and Konings (2005) find substantial positive correlation between liberalization of trade in intermediate inputs and downstream manufacturing productivities. Some case studies (Arnold et al, 2006; Fermandes and Caroline, 2008) also find substantial positive correlations between FDI in services and the growth of manufacturing labor productivities.

2. Backward-linkage technology spillovers. Take wholesaling and retailing industry as an example. Gereffi (1994) categorizes global production chains into two types, producer-driven and buyer-driven. The latter is driven by large retailers, which engage in designing and marketing, and outsource production process to manufacturing suppliers. Large multinational retailers often require their suppliers to reduce costs and improve quality. Moreover, because multinational retailers usually 
have better distribution efficiencies, suppliers in manufacturing sectors compete to enter, which gives manufacturers incentives of improving quality and reducing costs.

3. Strengthened technology spillover effect. Compared to FDI in manufacturing sectors, FDI in services have stronger technology spillover effects, because the spillover effect FDI in services has on manufacturing industries is inter-industry, while in manufacturing FDI cases, there could be either inter-industry or intra-industry. Theoretical and empirical finds that inter-industry technology spillover is easier to occur ${ }^{1}$.

Soft technology transfers brought by manufacturing multinationals are mainly organization-wide, therefore the producer services that produce soft technologies will only support the manufacturing process for local branches of multinationals, instead of being transferred by trade or licensing (Markusen, 1995). Local manufacturing enterprises can only obtain soft technologies from manufacturing TNCs through non-market activities such as cooperative effect, competition effect and demonstration effect and so on.

FDI in service sectors, especially FDI in producer services are the manifestation of producer service "externalization" in globalized world, which expand specialization and division of labor to host countries. Market-seeking FDI in the services target local enterprises in host countries as clients from the very beginning; those who follow their existing clients into host countries will finally extend their client base to local manufacturing companies. For example, at present, over $70 \%$ of revenues of the majority of foreign management consulting firms in China come from local customers. In this sense, services FDI has stronger technology spillover effects on local manufacturing enterprises in host countries.

4. FDI in services has interactions with that in manufacturing sectors. First of all, some FDI in services are from manufacturing multinational companies, providing support to their business in host countries, especially in trade and finance. Second, client-following FDI can enhance operational efficiencies of foreign manufacturing companies in host countries. Moreover, the existence of services FDI provide sound infrastructure for manufacturing companies; and with overseas business matures, service MNCs also encourage their customers in home countries to expand their business in host countries (Daniel, 1993). Case studies on Japan finds in late 1980s and early 1990s, the presence of Japanese MNCs in service sectors brought new Japanese multinationals in manu-

$\overline{{ }^{1} \text { For a literature review about inter-industry and intra-industry tech- }}$ nology spillover, see Jing Peng, Co-development of MNCs and Local Enterprises: From Backward Linkage to Horizontal Linkage. CASS Dissertation, 2005. facturing sectors. The study proposes two reasons: technological advances make services a more important input in manufacturing sectors; relative to large-scale manufacturing enterprises, smaller manufacturing enterprises rely more on existing service provider networks, and the presence of Japanese service multinationals reduced overseas investment cost. Chyau Tuan and Linda FY Ng (2003) make a case study on Guangdong Province in China, which finds substantial correlations between location choices of manufacturing and service FDI, especially between small and medium foreign manufacturing enterprises and FDI in services, and its large-scale service enterprises with FDI location choice of the highest correlation.

5. Helping upgrade the structure of exportation. Since many services are not internationally tradable, it is generally believed that FDI in services has minor influences on the exports of the host country. (UNCTAD, 2006). However, many producer services can provide critical input to manufacturing sectors in host countries, thus changing the comparative advantages of manufactured goods and improving their export competitiveness (Markusen et. Al., 2005). Francois and Woerz (2007) find that services make the largest contributions to exportation of goods. Producer service liberalization is significantly positively correlated with exportation competitiveness of service- and technology-intensive products, but has a significant negative correlation with exportation performance of non-service-intensive products. Wolfmayr.Y. (2008) tests the correlations between service linkage and market share of the exported manufactured goods, and finds international service linkage has the significant positive effects on high-tech. products exportation.

\subsection{Indirect Channels}

1. Encouraging local service providers to improve service quality. Blind and Jungmittag (2004) found that FDI and imports of services have significant positive effects on the service product and process innovation. Some case studies also proved the effect of international service on local service innovation. For example, during the privatization of communications industries in Argentina in 1980s, the introduction of foreign equity participation have a very big effect on the improvement of communication infrastructure and the quantity and quality of services. Within two years of the reform, the two major communications companies, Telefonica and Telecom, increased 330,000 and 270,000 lines respectively, while in the five years prior to the reform, Telecom, originally known as ENTel only increased 98,000 lines; In addition, the companies also update their technologies to digital systems (Bernard Hoekman et al., 1997).

2. Bringing more service varieties. Services are more 
differentiated than manufactured goods. Therefore, services by multinational providers are more of complementary than substitution with local service providers. Case study about FDI liberalization in services in Russia finds that, FDI in services brings a net increase of service varieties, though competition forced some local service providers to exit the market ${ }^{2}$. Other case studies about Turky, Hungary, Mexico, and Chili also provide such evidences (Denizer, 1999; McBride, 2004; Cardenas et al., 2003; ECLAC, 2000). More service varieties help generate Dixit-Stiglitz-Either effect, raising the downstream manufacturing enterprises total factor productivity (Dixit, A. and J. Stiglitz, 1977; Either, WJ, 1982).

3. Pushing the service price down. The reasons are twofold. First, FDI intensifies competition, forcing service companies to reduce costs. Sometimes the presence of multinational corporations breaks the monopoly market structure. The original monopoly is no longer able to obtain monopoly rents (Fernandes, Ana M.and Paunov, Caroline, 2008) Classen et.al. (2001) finds that between 1988 and1995, introductions of foreign banks intensified the competition in the local banking sector, and profit rates were lowered. Second, for the transnational service corporations, expanding into foreign markets help them achieve economies of scale, resulting in possible lower costs. Service production is differentiated and enjoys increasing marginal returns, which rely on bigger market to achieve scale economies (Markusen, 1989). Case studies about Chili, Mexico and Australia provide some evidences ${ }^{3}$.

4. Posing a demonstration effect. FDI in services brings multinational service corporations, who, with better service output and more experienced management, are a very good opportunity for local firm to learn. The demonstration effects of service MNCs is easier to occur than that of manufacturing MNCs, because most service production and consumption cannot be separated, making it difficult to keep for technical secret. (Jiang Xiaojuan, 2004).

5. Being the key channel of cross-border technology spillover in service area. Since service consumption and production cannot be separated, the soft technology in services can only be transferred internationally through FDI. Moreover, human resources is the main carrier of the soft technology, and multinational corporations provide the best organizational and institutional arrangements for cross-border mobility of human resources. In some service areas (e.g. advertising and management consulting), technologies are "embedded" in the complex relationships and communications within the organ-

\footnotetext{
${ }^{2}$ See Jesper Jense, Thomas Rutherford and David Tarr, The Impact of Liberalizing Barriers to Foreign Direct Investment in Services: The Case of Russian Accession to the World Trade Organization.

${ }^{3}$ See Bernard Hoekman et.al.(1997)
}

izations, which is very hard to be copied by other companies. But it becomes much easier when it is between headquarters and local branches of one multinational company. Finally, value chain in the production of most services can hardly be decomposed, therefore the technology gap between multinational headquarter and branches in host countries is much smaller than that in manufacturing industries, making it easier for host country to obtain the service technologies(Jiang Xiaojuan, 2004). Grosse (1996) finds that only a very small part of the service firms transfer technologies through channels other than FDI.

\section{Model}

The regression equation is the following:

Regression 1:

$$
\begin{aligned}
\ln \text { Pro }_{i t} & =\alpha_{0}+\alpha_{1} \ln \text { Backlink }_{i t}+\alpha_{2} \ln \text { Forlink }_{i t} \\
& +\alpha_{3} \ln \text { Cap }_{i t}+\alpha_{4} \ln \text { Size }_{i t}+\varepsilon_{i t}
\end{aligned}
$$

Where Pro $_{i t}$ is the labor productivity of manufacturing industry $i$ at the year $t$, which is calculated as value added divided by number of working staff. Cap ${ }_{i t}$ is the capital per person, calculated as physical capital formation divided by number of working staff. Sizeit is the average size of firms in the manufacturing industry $i$ at year $t$, calculated as total number of working staff divided by number of firms in the industry. $\mathrm{Cap}_{i t}$ and Size $_{i t}$ are control variables, representing technological levels and economies of scale.

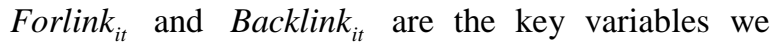
are examining, respectively referring to forward-linkage and backward linkages between manufacturing industry and FDI in services. When constructing the two variables, the basic idea is as follows: first obtain "the service input in manufacturing industries" and "manufacturing output that is put into the service sectors", then catch the part of two values that is related to foreign service firms with some structural variables.. Since the dependant variable is labor productivity, Forlink $k_{i t}$ and Backlink should also be per capita value, therefore number of labors is used to calculate the average value.

Therefore, the two variables are constructed as follows.

$$
\begin{aligned}
& \text { Forlink }_{i t}=\frac{\text { SerFDI }_{t}}{\text { SerInv }_{t}} \times \frac{\text { SerInput }_{i t}}{\text { Labor }_{i t}} \\
& \text { Backlink }_{i t}=\frac{\text { SerFDI }_{t}}{\text { SerInv }_{t}} \times \frac{\text { InutSer }_{i t}}{\text { Labor }_{i t}}
\end{aligned}
$$

where Forlink $k_{i t}$ measures service input per person in manufacturing industry $i$ in year $t$ that is provided by foreign service providers; $\frac{\operatorname{SerFDI} I_{t}}{\operatorname{SerInv} t_{t}}$ is the percentage of 
service FDI in total investment in service sectors, which give the importance of foreign firms in the service sector.

$\frac{\text { SerInput }_{i t}}{\text { Labor }_{i t}}$ is service input per person into industry $i$ at year $t$.

Backlink $_{\text {it }}$ measures the per-person average manufacturing output that is put into foreign service firms; $\frac{\text { InputSer }_{i t}}{\text { Labor }_{i t}}$ is the output per person of industry $i$ in year $t$ that is put into the service sectors.

Two points need to be mentioned here. First, for structural variable, it is better to use the percentage of output of foreign service firms in total service output. However, due to data availability problem, percentage of investment is used instead. Second, the variable construction can also be used to reflect the backward and forward linkage between manufacturing industries and FDI in some particular service industries. Therefore, we can have regression 2 as follows:

Regression 2:

$$
\begin{aligned}
\ln \text { Pro }_{i t} & =\alpha_{0}+\alpha_{1} \ln \text { tran }_{i t}+\alpha_{2} \ln \text { btran }_{i t} \\
& +\alpha_{3} \ln \text { rnd }_{i t}+\alpha_{4} \ln \text { brand }_{i t}+\alpha_{5} \ln \text { sale }_{i t} \\
& +\alpha_{6} \ln \text { bsale }_{i t}+\alpha_{7} \ln \text { Cap }_{i t}+\alpha_{8} \ln \text { Size }_{i t} \\
& +\alpha_{9} \text { AR(1) }+\varepsilon_{i t}
\end{aligned}
$$

where trand $_{i t}$, rnd $d_{i t}$ and sale st measure forward- linkage effect between manufacturing industry $i$ and FDI in transportation, R\&D and retailing \& wholesaling industries; and the backward linkage are measured by btran $_{i t}$, brnd $_{i t}$ and bsale $_{i t}$, respectively.

Transportation, R\&D and retailing \& wholesaling industries are chosen as typical producer services for two reasons. First, they are more of producer service nature; second, better data are available for them.

\section{Data}

A panel data of 15 industries with time series from year 2001 to 2008 is used. The Industry classification is based on input-output table in China. The industry classifications in "China Statistical Yearbook" and "China Industrial Economy Statistical Yearbook" are adjusted and combined to match the input-output tables classification.

Data sources include China Statistics Yearbook, China Industrial Statistics Yearbook, Input- Output Table of China(2002, 2005, 2007). All the data has been adjusted to be comparable. Because input-output data are available for only limited years, input-output data for 2002 are used to represent year 2001-2003; data for 2005 represent year 2004-2005; data for 2007 are used to represent year 2006-2008.

\section{Result}

\begin{tabular}{|c|c|c|}
\hline Dependant variables & Model 1 & Model 2 \\
\hline Constant & 6.034951*** & 6.157733*** \\
\hline ln Backlink & $0.047701^{* *}$ & \\
\hline ln Forlink & $0.064076^{* *}$ & \\
\hline ln tran & & $-0.267967 * * *$ \\
\hline ln btran & & $0.077903^{* *}$ \\
\hline $\ln r n d$ & & $0.162076^{* * *}$ \\
\hline ln brand & & -0.013762 \\
\hline ln sale & & $0.245397 * * *$ \\
\hline In bsale & & $0.062997 * * *$ \\
\hline $\ln$ Cap & $0.466369 * * *$ & $0.327844 * * *$ \\
\hline ln Size & $0.148883^{* *}$ & $0.284671^{* * *}$ \\
\hline $\ln A R(1)$ & $0.898923 * * *$ & $0.903330 * * *$ \\
\hline \multicolumn{3}{|l|}{ Fix effects } \\
\hline 1--C & 0.360211 & 0.312150 \\
\hline 2--C & -0.252174 & -0.089820 \\
\hline 3--C & -0.582144 & -0.547706 \\
\hline 4--C & -0.233206 & 0.160792 \\
\hline 5--C & -0.538998 & -0.193214 \\
\hline 6--C & 0.296038 & 0.782074 \\
\hline 7--C & -0.001599 & 0.179099 \\
\hline 8--C & 0.035685 & 0.594953 \\
\hline 9--C & 0.904339 & 0.754525 \\
\hline 10--C & 0.060737 & 0.179189 \\
\hline 11--C & 0.371601 & 0.238329 \\
\hline 12--C & 0.091197 & -0.618255 \\
\hline 13--C & 0.082510 & -0.047681 \\
\hline 14--C & -0.594732 & -1.381561 \\
\hline $15--C$ & 0.000534 & -0.322864 \\
\hline R2 & 0.994580 & 0.998631 \\
\hline Adjusted R2 & 0.993369 & 0.997756 \\
\hline F statistics & 820.9578 & 1141.658 \\
\hline D--W statistics & 2.488180 & 2.974735 \\
\hline Prob(F-statistic) & 0.000000 & 0.000000 \\
\hline
\end{tabular}

Table 1 presents the estimation results, which is quite consistent with our anticipations. We have the following

Table 1. Dependant variable: $\ln$ Pro .

Note:***, ** represent $1 \%$ and $5 \%$ significance

findings: First, both forward and backward linkage effects between FDI in services and manufacturing sectors are positive and significant, which indicates, on the one hand, services FDI can enhance manufacturing labor productivity through providing services inputs to the manufacturing sectors. On the other hand, manufacturing efficiencies can also be enhanced when manufacturing firms provide inputs to Foreign Service firms, probably because foreign service firms set higher standards for their inputs, which force manufacturing firms improve their output. Secondly, we find that overall forward linkage is stronger than backward linkage. FDI in transportation, storage and communications has a substantial negative forward linkage effect on manufacturing efficiencies, but the backward linkage is positive. The negative forward linkage is inconsistent with anticipation, 
possibly because there is still substantial barrier blocking foreign investment in the industry, especially in areas like railroad transportations, basic communications and postal services. The positive backward linkage is easy to understand considering the substantial inter-industry connections with this industry. FDI scientific research and comprehensive technological services has substantial positive forward linkage effect with manufacturing industries. They provide research and development, which could be direct input into manufacturing sectors, helping improve manufacturing efficiencies. FDI in retailing and wholesaling services presents the most substantial inter-industry linkage effects with manufacturing sectors. Both forward and backward linkages are substantially positive, and the combination of the two is the biggest among all the service industries examined. In Chinas service sectors, retailing and wholesaling is the most open to foreign investment, thus the linkage effects is easier to be realized. Retailers and wholesalers are distributions channels of manufactured goods, which determine the product availability, sales efficiencies and customer services. With more experienced logistic management and better technologies, foreign distributors, especially multinational distributors, provides better services. On the other hand, by providing input to foreign distributors, manufacturing companies efficiencies are improved, probably because of the higher requirement and more intense competition in multinational distributors.

\section{Conclusions}

The paper first theoretically analyses the influences of FDI in services on efficiencies of manufacturing sectors in host countries, then studies the forward and backward linkage effects of FDI in services on manufacturing sectors with an industry panel data in China. We find both positive forward and backward linkage effects exist between FDI in services and Chinese manufacturing efficiencies. FDI in retailing and wholesaling industry has the most substantial inter-industry linkages. The finding implies that we need to have a comprehensive understanding of the significance of service liberalization, which can not only boost the development of local service sector by injecting more completion and demonstration effects, but also benefit the efficiency in manufacturing sectors through inter-industry linkages.

The study is preliminary for the following reasons. First, due to data availability problems, the study doesn't precisely capture the input-output relationship between FDI in services and manufacturing sectors in host countries. If we can get service output data and input-output data for more years, the empirical study will be more convincing. Moreover, many other channels where FDI in services influence manufacturing industries in host countries is not studied in this paper, for example, FDI in services and export of manufactured goods, interaction between FDI in services and in manufacturing sectors, which also give space for future research.

\section{REFERENCES}

[1] M. Amiti and J. Konings, Trade Liberalization, Intermediate Inputs and Productivity: Evidence from Indonesia. CEPR Discussion Paper 5104.

[2] B. Hoekman and C. A. P. Braga (1997), "Protection and Trade in Services: A Survey,” Open Economies Review, Vol. 8, No. 3, 1997, pp. 285-308. doi:10.1023/A:1008246932328

[3] K. Blind and J. Andre, "Foreign Direct Investment, Imports and Innovations in the Service Industry," Review of Industrial Organization,” Vol. 25, 2004, pp. 205-207. doi:10.1007/s11151-004-3537-X

[4] J. J. Boddewyn, Halbrich, Marsha Baldwin and A. C. Perry, "Service Multinationals: Conceptualization, Measurement and Theory,” Journal of International Business Studies, Vol. 17, No. 3. pp. 41-57. doi:10.1057/palgrave.jibs.8490860

[5] M. Casson (1986), The Firm and the Market: Studies on Transactions Cost and the Strategy of the Firms, Chapter 2. London: Basil Blackwell/Cambridge, Mass.: MIT Press.

[6] C. Tuan and F. Y. Ng Linda, FDI Facilitated by Agglomeration Economies: Evidence from Manufacturing and Services Joint Ventures in China," Journal of Asian Economics, Vol. 13, 2003, pp. 749-765. doi:10.1016/S1049-0078(02)00183-5

[7] R. Cowan, L. Soete and O. Tchervonnaya, "Knowledge Transfer and the Service Sector in the Context of the New Economy,” MERIT-Infonomics Research Memorandum series. June, 2001.

[8] P. W. Daniels, Service Industries in the World Economy, Oxford: Oxford University Press. 1993.

[9] A. Dixit and J. Stiglitz, "Monopolistic Competition and Optimum Product Diversity,” American Economic Review, 1977, Vol. 67, pp. 297-308.

[10] W. J. Ethier, 'National and International Returns to Scale in the Modern Theory of International Trade", American Economic Review, Vol. 72, No. 2, 1982, pp. 389-405.

[11] W. Ethier, "Internationally Decreasing Costs and World Trade,” Journal of International Economics, February 1979. 9.

[12] Ana M. Fernandes, C. Paunov, Service FDI and Manufacturing Productivity Growth: There is a Link. Working Paper, World Bank, April 2008.

[13] J. F. Francois, "Producer Services, Services, and the Division of Labor," Oxford Economic Papers, New Series, Vol. 42, No. 4, 1990, pp.715-729.

[14] J. Francois and J. Woerz, "Producer Services, Manufacturing Linkages and Trade,” Tinbergen Institute Discussion Paper, TI2007-045/2, 2007, downloadable at http://ssrn.com/abstract=993361

[15] G. Gereffi, “The Organization of Buyer-Driven Global 
Commodity Chains: How US Retailers Shape Overseas Production Networks,” In G. Gereffi \& M.(Eds.), Commodity Chains and Global Capitalism,.Westport, CT: Praeger, pp. 92-122.

[16] B. Gold, “On Size, Scale, and Returns: A Survey,” Journal of Economic Literature, Vol. 19, 1981, pp. 5-33.

[17] H. I. Greenfield, Manpower and the Growth of Producer Services, New York \& London: Columbia University Press, 1966.

[18] R. Griffith, S. Redding and H. Simpson, "Foreign Ownership and Productivity: New Evidence from the Service Sector and the R\&D Lab,” Working Paper, the Institute for Fiscal Studies, 04/22, 2004.

[19] D. M. Gross, H. Raff and M. J. Ryan, Intra- and Inter-Industry Linkage in Foreign Direct Investment: Evidence from Japanese Investment in Europe.

[20] R. Grosse, "International Technology Transfer in Services,” Journal of International Business Studies, Vol. 27, No. 4, pp. 781-800.

[21] E. Helpman, M. Melitz and S. Yeaple, "Export Versus FDI with Heterogeneous Firms," American Economic Review, 2004.doi:10.1257/000282804322970814

[22] B. Hoekman, Trade in Services at 25: Theory, Policy and Evidence, World Bank, mimeo.

[23] I. J. Horstmann and J. R. Markusen, "Firm-Specific Assets and the Gains from Direct Foreign Investment," Economic, New Series, Vol. 56, No. 221, pp. 41-48.

[24] J. R. Markusen, "The Boundaries of Multinational Enterprises and the Theory of International Trade," The Journal of Economic Perspectives, Vol. 9, No. 2, 1995, pp. 169-189. doi:10.1257/jep.9.2.169

[25] J. Arnold, B. S. Javorcik and A. Mattoo, "Does Services Liberalization Benefit Manufacturing Firms?” Evidence from the Czech Republic. September, 2006.

[26] J. Jensen, T. F. Rutherford and D. G. Tarr, "The Impact of Liberalizing Barriers to Foreign Direct Investment in Services: The Case of Russian Accession to the World Trade Organization," World Bank Policy Research Working Paper, No. 3391. August 2004. Downloadable at http://papers.ssrn.com/sol3/papers.cfm?abstract_id=6252 68.

[27] J. Jensen, T. Rutherford and D. Tarr, The Impact of Liberalizing Barriers to Foreign Direct Investment in Services: The Case of Russian Accession to the World Trade Organization.

[28] J. R. Lombard, "Foreign Direct Investment in Producer Services: the Role and Impact upon the Economic Growth and Development of Singapore,” Doctorate Dissertation of State University of New York at Buffalo.

[29] M. A. Atouzian, "The Development of the Service Sector:
A New Aproach,” Oxford Economic Papers, Vol. 22, 1970, pp. 362-383.

[30] M. Teresa Fernandez Fernandez, "Performance of Business Services Multinational in Host Countries: Contrasting Different Patterns of Behaviour between Foreign Affiliates and National Enterprises," The Service Industries Journal, Vol. 21, No. I, pp. 5-18.

[31] J. R. Markusen, T. F. Rutherford and D. G. Tarr, "Foreign Direct Investment in Services and the Domestic Market for Expertise,” NBER Working Paper No. W7700. Downloadable at http://papers.ssrn.com/sol3/papers.cfm?abstract_id=2289 92

[32] J. R. Markusen, "Trade in Producer Services and in Other Specialized Intermediate Inputs," The American Economic Review, Vol. 79, No. 1.1989, pp. 85- 95.

[33] J. M. Markusen, T. F. Rutherford and D. Tarr, “Trade and Direct Investment in Producer Services and the Domestic Market for Expertise," Canadian Journal of Economics, Vol. 38, No. 3, 2005. doi:10.1111/j.0008-4085.2005.00301.x

[34] P. Karaty and A. Poldahl, "The Determinants of FDI Flows: Evidence from Swedish Manufacturing and Service Sector,” April 28, 2006.

[35] R. Grosse, International Technology Transfer in Services. Journal of International Business Studies, Vol. 27, No. 4, 1996, pp. 781-800. doi:10.1057/palgrave.jibs.8490153c

[36] A. M. Rugman, 1981, Inside the Multinationals: The Economics of Internal Markets. London: Croom Helm/New York: Columbia University Press.

[37] Y. Wolfmayr, "Producer Services and Competitiveness of Manufacturing Exports,” FIW Research Report No 009/Export of Services, June 2008.

[38] N. H. Gu, D. D. Bi and W. B. Ren, Interactive Development between Producer Servicve Sectors and Manufacturing Sectors: A Literature Review, Economist, 2006.6.

[39] X. J. Jian, Service Globalization and Outsourcing: Status Quo, Trends and Theoretical Analysis, Beijing: People Press, 2008.11.

[40] X. J. Jiang, Policy Suggestions on Expediting Service Sector Development, Review of Economic Research, 2004, 15.

[41] S. T. Li and C. S. Gao, Development of Chinese Producer Service Sector and Upgrading of the Manufacturing Industries, Shanghai Sanlian Press, 2008.11

[42] L. B. Luo, FDI in Services and Efficiencies of Manufacturing Sectors in Host Countries, International Economics and Trade Research, 2009.8.

[43] X. H. Wang, Chinese Design: Service Outsourcing and Competitiveness, Beijing: People Press, 2008.7 